\title{
The Effect of Training Program on Physical Characteristics and Social Development of Boys
}

Fatma Celik Kayapinar

Associate Professor, Mehmet Akif Ersoy University, School of Physical Education and Sport, Burdur, Turkey

fkayapinar@mehmetakif.edu.tr

Recep Aydemir

Mehmet Akif Ersoy University, School of Physical Education and Sport, Burdur, Turkey

reeeceep@hotmail.com

\section{Demet Hancer Aydemir}

Assistant Professor, Suleyman Demirel University, Vocational School of Health Services, Isparta, Turkey

demetaydemir@sdu.edu.tr

Doi:10.5901/ajis.2015.v4n1s2p139

\section{Abstract}

Sport is important for physical and social development of children. Through sports, recognition of the environment and communication with his/her environment takes place more easily for children. The aim of this research was to examine the effects of regular physical activity on physical and social developments of boys at 11 ages. The population of the study consisted of 11-years-old children. The sample group consisted of 10 children who want to participate in training and signed permission documents by their parents. In this study, 70 minutes of training program was implemented 2 days in a week during 12 weeks. The program was practiced 30 minutes games, 10 minutes stretching and the last half-hour handball abilities for developing physical skills and social abilities. In order to examine the social development, interviews were done with students and parents pre and last weeks of training by asking questions about some demographic characteristics, communication and expectations. In the analysis of the obtained data software package programme and content analysis was used. According to the result of this research, students developed taking responsibility and their communication skills. It was determined that the best friends of the students selected from the group who participated in training, They wanted to play handball as a professional in the future and their expectations from this education program realized. In addition, there was meaningfull increase at height and weight values.

Keywords: boys, physical characteristics, preference of friend, social development

\section{Introduction}

Sport is a collective noun and usually refers to a range of activities, processes, social relationships and presumed physical, psychological and sociological outcomes. These activities include individual, partner and team sports; contact and non-contact sports; motor driven or perceptually dominated sports; different emphases on strategy, chance and physical skills; and competitive, self-development and purely recreational activities. A Council of Europe report suggests that sport provides opportunities to meet and communicate with other people; to take different social roles; to learn particular social skills (such as tolerance and respect for others); to adjust to team/collective objectives (such as cooperation and cohesion); and that it provides experience of emotions that are not available in the rest of life (Bailey, 2005).

The perceived and objective benefits of participation in sports for children are numerous and span multiple domains, including physical, physiological, and social development. In addition to promoting movement, sports provide a venue for learning, practicing, and developing gross motor skills. Sport provides a medium for physical activity, developing friendships, and learning developmental skills across all domains. Organized sports, when focused on fundamentals, facilitate physical activity while providing enjoyment for the participants (Merkel, 2013).

Through sport and exercise, participants interact with others and maintain social relationships (Vilhjalmsson and 
Thorlindsson, 1998). Through interactions with adults and peers, children should learn appropriate behavior and learn how to manage their emotions. For example, the amount of physical play between parents and their preschool children has been associated with greater social competence of youth. Through the self-regulation and the development of interpersonal and problem-solving skills, physical play is central toy he development of social competence. Participation in sport alone does not result in the development of positivie social and emotional characteristics. There is also a positive relationship between physical competence, interpersonal skils, and peer acceptance. Development of competencies also relates to sel-esteem. When others acknowledge their success in sport and physical activity children gain a sense of worthiness and a growing sense of confidence in their ability to succeed in the execution of the skills (Ewing et al. , 2002). Despite all the benefits physical activity may have, researchers and educators repeatedly report that many people are physically inactive (Vilhjalmsson and Thorlindsson, 1998).

In this context, sport is important for physical and social development of children. Through sports, recognition of the environment and communication with his/her environment takes place more easily for children. The aim of this research was to examine the effects of regular physical activity on physical and social developments of boys at 11 ages.

\section{Research Methods}

\subsection{Research Group}

The population of the research consisted of 11-years-old children in Isparta/Türkiye. The sample group consisted of 10 boys who volunteered participate in handball training and signed permission documents by their parents. Before acceptance, children's parents were fully informed about the objectives and methods of the research. Children and their parents are not forced to participate in the research.

\subsection{Data Collection}

In this research, 70 minutes of training program was implemented 2 days in a week during 12 weeks between June 14 and August 31, 2014. The program was practiced 30 minutes games, 10 minutes stretching and the last half-hour handball abilities for developing physical skills and social abilities. In order to examine the physicial and social development, anthropometric measurements (height, body weight, body mass index BMI) on the participants were performed and face to face interviews were done with students and parents pre and last weeks of training by asking open-ended questions about some demographic characteristics, communication and expectations. Body weight was measured in light clothing and with shoes removed, using a digital scale. Height was measured without shoes with a portable stadiometer. The data obtained was recorded in $\mathrm{cm}$ and $\mathrm{kg}$. BMI was calculated in $\mathrm{kg} / \mathrm{m}^{2}$.

\subsection{Statistical Analysis}

All data were analyzed using SPSS 16. 0 program pack. Frequency analysis was used to determine the children's age, height, body weight and also expectations of children and their parents from the sport. The Wilcoxon test was used for comparing the values of pre and post-test, height, body weight and BMI of participants. In analysis, a probability level of $P<0.05$ was used to indicate statistical significance.

\section{Findings}

As shown in Table 1, the students height, body weight, and body mass index mean values were found to be $154.50 \pm 9$. $08 \mathrm{~cm}, 47.97 \pm 12.70 \mathrm{~kg}$ and $19.76 \pm 3.73 \mathrm{~kg} / \mathrm{m}^{2}$ respectively.

Table 1. Findings related to height, body weight and body mass index values of the children who participated in the research.

\begin{tabular}{|ll|ll|ll|}
\hline 1. & Variable & 2. & Mean $(\mathbf{n}=\mathbf{1 0})$ & 3. & Standard deviation $(\mathbf{n}=10)$ \\
\hline 4. & Height $(\mathrm{cm})$ & 5. & 154,50 & 6. & 9,089 \\
\hline 7. & Body weight $(\mathrm{kg})$ & 8. & 47,97 & 9. & 13,706 \\
\hline 10. & BMI $\left(\mathrm{kg} / \mathrm{m}^{2}\right)$ & 11. & 19,76 & 12. & 3,739 \\
\hline
\end{tabular}


It has been determined that the primary goal of the children participating in the study from handball is having a developed body from the physical point of view. In addition, the ratio of those who were aiming to learn handball sports and become a handball player, have fun while doing sports and expand their friendship environment was around 18. 2\%. It has been also concluded that the ratio of those playing handball for recreation purposes and having a disciplined life was $4.5 \%$ (Table 2).

Table 2. Findings related to expectations of the children from handball training program.

\begin{tabular}{|c|c|c|}
\hline 13. What are your expectations from handball training program? & 14. $\mathrm{n}$ & 15. $\%$ \\
\hline 16. Learn handball sports and become a handball player & 17. 4 & 18. 18,2 \\
\hline 19. Have a developed body & 20. 8 & 21. 36,4 \\
\hline 22. Have fun doing sports & 23. 4 & 24. 18,2 \\
\hline 25. Expand my friendship environment & 26.4 & 27. 18,2 \\
\hline 28. Recreation & 29. 1 & 30. 4,5 \\
\hline 31. Have a disciplined life & 32. 1 & 33. 4,5 \\
\hline 34. Total & $35 . \quad 22$ & 36. 100,0 \\
\hline
\end{tabular}

According to the opinions of the students participating in the research, it has been determined that $90 \%$ of the participants think that they have achieved their expectations. Only $10 \%$ of the participants think that they haven't achieved their expectations (Table 3).

Table 3. Findings related to realization level of expectations of students from handball after training program

\begin{tabular}{|ll|cc|cc|}
\hline 37. & Have you achieved your expectations after training program? & 38. & $\mathbf{n}$ & \multicolumn{3}{|c|}{39.} & $\%$ \\
\hline 40. & Yes & 41. & 9 & 42. & 90,0 \\
\hline 43. & No & 44. & 1 & 45. & 10,0 \\
\hline 46. & Total & 47. & 10 & 48. & 100,0 \\
\hline
\end{tabular}

$70 \%$ of the students participating in the study think that they had significant changes in their friendship environments after handball training program, while $30 \%$ of the students think that they didn't have any significant changes in their friendship environments (Table 4).

Table 4. Findings related to changes seen in the friendship environments of the students after the training program

\begin{tabular}{|c|c|c|c|c|}
\hline 49. & Did you have any changes in your friendship environment after handball training program? & 50. $\mathrm{n}$ & & \\
\hline 52. & Yes & 53. 7 & 54 & 70,0 \\
\hline & No & 56. 3 & 57 & 30,0 \\
\hline & Total & 59. & 60. & 100,0 \\
\hline
\end{tabular}

Considering views of the participants at the end of the training program, it has been determined that $90 \%$ of them would like to be a handball player in the future, whereas only $10 \%$ of them don't want to be a handball player (Table 5).

According to the views of parents, parents expect their children, who play handball, to be socialized, disciplined and responsible. In addition, it has been determined that they want their children to be a good athlete, supported in terms of physical development, to expend their friendship environments, have the team and fighting spirit (Table 6).

Table 5. Findings related to future plans of the participants regarding whether they would like to be a handball player

\begin{tabular}{|c|c|c|}
\hline 61. Would you like to be a handball player in the future? & 62. $\mathrm{n}$ & 63. $\%$ \\
\hline 64. Yes & 65. 9 & 66. 90,0 \\
\hline 67. No & $\begin{array}{ll}68 . & 1\end{array}$ & $69 . \quad 10,0$ \\
\hline 70. Total & 71. 10 & 72. 100,0 \\
\hline
\end{tabular}


Table 6. Findings related to the expectations of parents of the participants from handball

\begin{tabular}{|c|c|c|}
\hline 73. Expectations & 74. $\mathrm{n}$ & 75. $\%$ \\
\hline 76. $\quad$ Being responsible and disciplined & 77. 8 & 78. 28.6 \\
\hline 79. Socialization & 80. 8 & 81. 28.6 \\
\hline Being a good athlete & 83. 4 & 14.3 \\
\hline 85. $\quad$ Physical development & 86. 3 & 87. 10.7 \\
\hline 88. Expanding the friendship environment & 89. 1 & $90 . \quad 3.6$ \\
\hline 91. Gaining the team and fighting spirit & 92. 4 & $93 . \quad 14.3$ \\
\hline 94. Total & $95 . \quad 28$ & $96 . \quad 100.0$ \\
\hline
\end{tabular}

According to the opinions of all the parents received at the end of the study, their children were socially improved at the end of the training program (Table 7).

Table 7. Findings related to socialization level of children after they start playing handball according to the views of parents

\begin{tabular}{|c|c|c|}
\hline 97. Do you think your children improved socially at the end of the training program? & 98. $\mathrm{n}$ & $99 . \%$ \\
\hline 100. Yes & 101. 10 & 102. 100 \\
\hline 103. No & 104. 0 & 105. 0 \\
\hline 106. Total & 107. 10 & 108. 100 \\
\hline
\end{tabular}

It has been determined that there was a statically significant development in the pre-test heights of the children $(p<0.05)$. In addition, body weight of the students increased, whereas their body mass indexes were decreased. However, it has been concluded that the changes occurred in body weights and body mass indexes of the students were statically insignificant $(p<0.05)$ (Table 8).

Table 8. Comparisons of pre-post test results of the participants regarding their height, weight and body mass index

\begin{tabular}{|c|c|c|c|c|c|}
\hline 109. Variable & 110. Pre-post test & 111. Mean & 112. Standard deviation & 113. Z & 114. $p$ \\
\hline \multirow{2}{*}{ 115. Height $(\mathrm{cm})$} & 116. Pre-test & 117. 154,50 & 118. 9,089 & \multirow{2}{*}{ 119. $-2,820$} & \multirow{2}{*}{ 120. ,005 } \\
\hline & 121. Post-test & 122. 156,30 & 123. 9,214 & & \\
\hline \multirow{2}{*}{ 124. Weight $(\mathrm{kg})$} & 125. Pre-test & 126. 47,97 & 13,706 & \multirow{2}{*}{ 128. $-1,914$} & \multirow{2}{*}{ 129. ,056 } \\
\hline & 130. Post-test & 131. 48,60 & 13,404 & & \\
\hline \multirow{2}{*}{ 133. BMI $\left(\mathrm{kg} / \mathrm{m}^{2}\right)$} & 134. Pre-test & 135. 19,76 & 3,739 & \multirow{2}{*}{ 137. $-1,580$} & \multirow{2}{*}{ 138. 114 } \\
\hline & 139. Post-test & 140. 19,56 & 3,513 & & \\
\hline
\end{tabular}

\section{Discussion and Results}

In this study, it has been determined that the primary goal of the children participating in the study from handball is having a developed body from the physical point of view followed by expectations such as learning handball sport and becoming a handball player, having fun while doing sports and expending their friendship environment. In addition, it has been concluded that most of these children think that they meet their expectations regarding handball. Besides, after handball training program, it has been also determined that the majority of children participated in the study wants to be a handball player in the future.

In a study conducted by Şirin et al. (2008), the biggest factor was identified to be the factor of entertainment leading people to sports. In another study conducted by Alibaz et al (2006) on amateur athletes, it has been determined that having fun is the most important factor expected by athletes from doing sports. In the study of Ölçücü et al. (2012) regarding tennis players, the main expectations of tennis players are determined to be healthy and having a good physical appearance. In the study of Şimşek and Gökdemir (2006) conducted on athletics athletes, the primary expectations of these athletes were determined to be selected for national team, having a college education in sports, being a good athlete and earning their lives from sports. It can be said that results of our study are consistent with results of these studies in the literature. In this context, the main expectations of these children from sports are having a healthy life, being a good athlete, expending the social environment and having fun. 
The parents expect their children playing handball to gain a sense of discipline and responsibility. They also want their children to be supported for their social developments. According to the parents' opinions received at the end of the study, their children were socially improved at the end of the training program. These findings support the idea that regular sports activities will contribute to children's social development.

Various studies demonstrated that young people's participation in sport supports their social development (Özdinç, 2005). According to YIImaz (2013), the physical education and sports activities are very important for supporting the physical development of young people in addition to raising individuals aware of their rights, respectful to each other, confident with accelerated socialization processes. According to Şahan (2008), sports activities allow people to have common activities. In this way, people gain a competitive structure, work discipline, and courage. In addition, in team sports, usually athletes are in physical contact with their opponents; however, in individual sports, they usually don't have any physical contact with their opponents. Therefore, it is not possible to demonstrate aggressive behaviors to their opponents in team sports (Güner, 2006). In the developed countries, where people are aware of the social benefits of sports, they give great importance to sports activities; therefore, children's sport and physical education programs start at very early ages (Duman and Kuru, 2010). The views of parents obtained in our study are consistent with these information obtained from the literature.

It has been determined that there has been a significant increase in height of the children participated in the study after the handball training program. There have been some insignificant changes in body weight and body mass index (increases in body weight, reduction in body mass index) of the children. According to these findings, we can say that the 12-week handball training supported the physical development of children in a positive way.

The support of these handball trainings in the physical development of children is a result consistent with the literature. In fact, in the studies conducted, it has been reported that children and young people's participation in sports support the physical development depending on physical and metabolic adaptation (Courteix et al. , 1998; Fuchs et al, 2001). In addition, it has been also stated that participation in sports is very important to prevent obesity and especially sedentary lifestyle that negatively affect physical development of children (Nemet et al. , 2005). In the study of Hekim (2014), it has been emphasized that ensuring the participation of children in sports starting from elementary school is quite significant for supporting the physical development of them.

As a result, it has been determined that the primary goal of the children participating in the study from handball is having a developed body from the physical point of view followed by expectations such as learning handball sport and becoming a handball player, having fun while doing sports and expending their friendship environment. In addition, it has been also determined that most of these children meet their expectations during handball trainings. The main expectation of the parents was supporting their children in terms of socialization. In addition, according to the views of parents, there were significant improvements in social aspects of the children at the end of the training programs. The positive changes occurred in the relationship between children support the views of parents. In addition to these, handball trainings were determined to be supportive in the physical developments of children from various aspects and it has been concluded that the findings of this study correlate with the literature. As a result, it can be said that handball trainings would be beneficial in terms of social and physical development of children.

\section{References}

Alibaz, A. , Gündüz, N. , \& Şentuna, M. (2006). Motives that prompt advanced taekwondo, karate and kick-box sportsmen to prefer these sports branches, reasons to be active in these branches and their expectations for the future. Spormetre Journal of Physical Education and Sports, 4 (3), 91-102.

Bailey, R. (2005). Evaluating the relationship between physical education, sport and social inclusion. Educational Review, 57 (1), $71-90$.

Courteix, D. , Lespessailles, E. , Peres, S. L. , Obert, P. , Germain, P. , \& Benhamou, C. L. (1998). Effect of physical training on bone mineral density in prepubertal girls: a comparative study between impact-loading and non-impact-loading sports. Osteoporosis International, 8 (2), 152-158.

Duman, S. , \& Kuru, E. (2010). The cooperation and determination of personal integration levels of Turkish students according to their sports participation level. Nigde University Journal of Physical Education and Sport Sciences, 4 (1), 18-26.

Ewing, M. E. , Gano-Overway, L. A. Branta, C. , \& Seefeldt, V. (2002). The role of sport in youth development. In M. Gatz, A. M. Messner, \& S. J. Ball-Rokeach (Eds), Paradoxes of Youth and Sport (pp. 31-47). Albany, New York: SUNY Press.

Fuchs, R. K. , Bauer, J. J. , \& Snow, C. M. (2001). Jumping improves hip and lumbar spine bone mass in prepubescent children: a randomized controlled trial. Journal of Bone and Mineral Research, 16 (1), 148-156.

Güner, B. Ç. (2006). Takım sporları ve bireysel sporlar yapan sporcuların saldırganlık düzeylerinin incelenmesi. Yüksek Lisans Tezi. Samsun; Ondokuz Mayıs Üniversitesi, Sağlık Bilimleri Enstitüsü, Beden Eğitimi ve Spor Anabilim Dalı. 
Hekim, M. (2014). İlköğretim öğrencilerinde fiziksel ve motor gelişimin desteklenmesinde spor ve fiziksel aktivitenin önemi. VI. International Congress of Educational Research, 5-8 June 2014, Hacettepe University, Ankara.

Merkel, D. L. (2013). Youth sport: positive and negative impact on young athletes. Open Access J Sports Med, 4, 151-160.

Nemet, D. , Barkan, S. , Epstein, Y. , Friedland, O. , Kowen, G. , \& Eliakim, A. (2005). Short-and long-term beneficial effects of a combined dietary-behavioral-physical activity intervention for the treatment of childhood obesity. Pediatrics, 115 (4), $443-449$.

Ölçücü, B. , Erdil, G. , Bostancı, Ö. , Canikli, A. , \& Aybek, A. (2012). The reasons of athletes who participate in intercolegiate tennis competitions for taking up tennis and their expectations. Journal of Sports and Performance Researches, 3 (2), 5-12.

Özdinç, Ö. (2005). The sentiments of Cukurova Unıversıty students on sports and the sports participation - socialization relationship. Spormetre Journal of Physical Education and Sports, 3 (2), 77-84.

Şahan, H. (2008). Üniversite öğrencilerinin sosyalleşme sürecinde spor aktivitelerinin rolü. Journal of Social and Economic Research, 10 (15), 260-278.

Şimşek, D. , \& Gökdemir, K. (2006). The reasons of students doing athletics in secondary scholl tending to athletics and their expectations. Spormetre Journal of Physical Education and Sports, IV (3), 83-90.

Şirin, E. F. , Çağlayan, H. S. , Çetin, M. Ç. , \& Ince, A. (2008). Determination of factors affecting sports participation motivation of high school students who make sports. Nigde University Journal of Physical Education and Sport Sciences, 2 (2), 98-110.

Vilhjalmsson, R. , \& Thorlindsson, T. (1998). Factors related to physical activity: a study of adolescents. Soc Sci Med, 47 (5), 665-675.

Yılmaz, S. (2013). Spor yapan ve yapmayan ortaöğretim öğrencilerinin empatik eğilimleri ile saldırganlık düzeyleri arasındaki ilişkinin incelenmesi (İstanbul ili Bayrampaşa ilçesi örneği). Yüksek Lisans Tezi, İstanbul; Yeditepe Üniversitesi, Sosyal Bilimler Enstitüsü, Eğitim Yönetimi ve Denetimi Anabilim Dalı. 